\title{
Strategic risk management in public policy: Conflict study approach ${ }^{*}$
}

\author{
A. V. Kurochkin, D. A. Maltseva \\ St. Petersburg State University, \\ 7-9, Universitetskaya nab., St. Petersburg, 199034, Russian Federation
}

For citation: Kurochkin A. V., Maltseva D. A. Strategic risk management in public policy: Conflict study approach. Vestnik of Saint Petersburg University. Philosophy and Conflict Studies, 2018, vol. 34, issue 2, pp. 264-276. https://doi.org/10.21638/11701/spbu17.2018.210

The article is dedicated to an analysis of the implementation of strategic risk management in public governance in highly a conflicted society. The main goal of the article is finding grounds for the formation of a risk management model based on the assessment and selection of adequate tools that mitigate the potential negative effects and consequences of risks. The increased pace of change and the low efficiency of public governance require pursuing different approaches to determining development strategies, assessing regulatory impact, widening the scope of stakeholders involved in the decision-making process. Political solutions should receive theoretical and methodological justification as integral solutions related to coordinating various goals in the policy-making process. An in-depth study of efficient administrative and managerial mechanisms, competencies and public governance capabilities that themselves provide public consent and lower the level of conflicts makes it possible to form new communicative spaces in public policy. These spaces must ensure a proper correlation between state interests and public needs and demands, public order and the particular functional standards for creating efficient political strategies. They also must provide real scenarios by which the state my resist destabilizing, negative factors. In highly conflicted societies vital importance is given to such practises as forecasting and strategic planning in institutions public governance. The main purpose of this is to diagnose patterns and factors that lead to risks which result in various social changes. Possible development options may then be identified which may evolve into the most efficient means of solving problems based on urgent managerial decisions. This point of view makes it possible not only to form the fundamental foundations of policy making concerning prognosis, prevention and managing conflicts, and to reconcile private and state interests, but also to overcome the level of social and political uncertainty.

Keywords: conflicts, risks, risk management, strategic management, public policy, governance, public interests.

Modern society is continuously becoming more and more dynamic, thus getting unpredictable in its development and increasingly hard to control. There is an ever widening range of political, social, cultural and economic conflicts, and their intensity, structure and content is becoming more complex. In their wake come global political and economic

* This research has received the support of a grant from the Russian National Fund for the Humanities №17-33-01134 'Strategic modelling in political rivalry and in the system of state governance’.

Исследование выполнено при поддержке гранта РГНФ № 17-33-01134 «Стратегическое моделирование в пространстве политической конкуренции и системе государственного управления».

(c) Санкт-Петербургский государственный университет, 2018 
crises that badly affect even states that are not actively involved in the conflicts themselves. That brings us to the point that it is of both theoretical and practical interest for scientists, as well as acting political managers, to shift towards using a strategic paradigm of conflict study as a preferable one. Two Russian scientists specializing in conflict studies, A. Aleinikov and A. Strebkov, came up with the following idea that 'analysing Russian society through the conceptual prism of singling out particular qualities and attributes that characterize the society, a prism that allows for testing that social system for equilibrium within its functioning and development and for the level of conflict it is still able to sustain, using this as an explanatory mode is the basic level of political realism' [1, p. 36]. The methodological basis for strategic analysis can be presented as a complex scientific approach that includes, among others, system theory, an institutional, functional and axiological approach, and communication management which clearly indicates the fact that strategic knowledge indubitably possesses integrative and inter-disciplinary content. It becomes more and more evident in the sense of creating an efficient model of conflict management in public policy based on knowledge and innovative digital technologies.

If one considers analysing the content itself, one may come to the conclusion that strategic management is actually a scientific framework that is aimed at increasing the operational effectiveness of managerial structures and decision-making processes through the implementation of procedural tools from management theory that, in a political sense, includes the following basic elements, among others:

1. creating intellectual and structural space for discussions that articulate the need for efficient reforms in the public sphere,

2. defining strategic aims and tasks,

3. providing stable informational channels for monitoring the environment and assessing the efficiency and rationality of the actions, performed by public actors,

4. implementation of strategic controlling mechanisms,

5. budgeting and analysing transaction costs,

6. a wide range of global risk-managment mechanisms.

To some extent, this keen interest in strategic management methodology in conflict studies has also been prompted by the crisis in previous managerial frameworks which had been primarily focused on a strictly utilitarian political agenda, which, in its course, had made the public governance process rather mobilizing than evolutional, based on setting political priorities and working through the alternatives conceptually. This is especially crucial in a situation when both domestic and foreign conflicts flourish and thus provoke an uncontrollable increase in uncertainty. Should one consider the problem from this angle, it eventually leads one to agree with the opinion of V. Kapustin who, reflecting upon the transformation of modern states in the long historical perspective, comes to the following conclusion: "The aggressiveness index of actions per time unit has risen dramatically. The universal escalation of contemporary global development has finally resulted in the fact that one million Paleolithic years is roughly equal to a span of just one generation nowadays. Instability and the ever increasing frequency of dissolution of order has become a typical reality in the modern world. The acceleration of new events appearing on the horizon not only shapes situations that are completely different but at the same time completely blocks even the remote possibility of going back to the past condition. The stochasticity of major socio-cultural processes every time and again brings about 'innova- 
tive cumulative effects' that completely destroy all the attempts to predict and forecast.... According to many scientists and the results of their research, there is a totally different character in the behavior of humankind that is called hyperbolic. Changes nowadays take place together with aggravation' [2].

In this way, strategies and scenarios that are developed and utilized in public governance can not be solely based on the examination of previous cases. This idea is essential in applying strategic analysis and risk-management procedures, which makes it possible to overcome the uncertainty level and to decrease the conflict and social tension level. If you consider risks as a whole, present and potential factors that have a negative effect to varying extents on the equilibrium and the evolution of society will clearly be visible. It would be a rather difficult task to classify properly, both theoretically and strategically, all the range of risks that either already exist or are still to come.

Considering all the varieties of risks, they can be divided into civilizational and national, regional and local. But they tend to transform themselves at such a rate that it leads to the emergence of new kinds and combinations that embrace various levels of the spread of threats.

The major types of risks are: demographic, social, economic, military, representational, cultural, and others (each of these categories could be subdivided into numerous parts that vary according to political régime, cultural and historical peculiarities, external forces, and so on). The character and consequences of conflicts appearing in a public sphere are shaped by the risks in socio-economic development (global economic crises, crisis of sovereignty of national states and supranational entities, the consequences of the growth in the digital economy, decrease in the level of trust in various levels of state and municipal government, the effect of 'post-truth' and the spread of populism, terrorism, etc.) in socio-cultural transformation (the digital gap, differences in the level of human capital, the rise of national and religious intolerance, etc.).

If one takes into account the modern-day environment concerning public management, then it is certainly worthwhile to note that all the attempts to implement elements of strategic management possess a highly reduced impact primarily due to the very specific design of public governance. Real strategic risk management procedures in contemporary Russia's public governance structure still seem to be wanting in effectiveness as implemented, though major efforts are being made to find a universal basis so as to arrive at a managerial practise that is focused on the future and that envisions a multi-optional scheme of future events. According to G. Pavlovsky 'Russian authorities are overloaded with uncontrollable conflicts, just as the former Soviet economics was with planning. No conflicts are resolved, and they cannot even be coped with, so busy are they making sure they do not trickle into politics. Not a single participant would ever find a moderator without a costly and time-consuming search. Not managing anything turned out to be a winning strategy for the authorities' [3, p.48]. This process is made even more complicated by the lack of development in the institutions of national public administration and in the ill-preparedness of political elites for real institutional, economic, political, and other transformations. The other essential factor is definitely the crisis of the strategic planning system itself, one which is getting worse rapidly. There are so many conceptual contradictions within the strategic paradigm which resulted because of its inability to cope with circumstances of force majeure. Despite being tired of all the speculations concerning 'the black swan' metaphor [4], it makes real sense to admit that the 'over-confidence' phenom- 
enon, that makes up the underlying idea of building strategies in contemporary network societies, together with making political and economic processes more formal via acquiring unified technologies (branded 'innovative'), dramatically influences the problem-solving in overcoming critically high instability and uncertainty levels. U. Beck remarked that all risks sooner or later catch up with those who produce them or benefit from them. As they spread, risks tend to create a boomerang effect, which essentially means this: those who already possess wealth and power are never guaranteed to stay clear of risks. All the 'side effects' that remain hidden for some time, later start to damage the very essence that originated them. Agents of modernization get caught into the very eye of the whirlpool that was actually brought about by them and that let them benefit from it for some time. It happens in various forms and shapes [5].

This brings us to a serious methodological problem. Applying strategic risk analysis and the conflict assessment procedures that are essential in risk management requires adhering to the principle of isomorphism (which basically means that all the events considered, with all their peculiarities, are similar and possess comparably functioning laws). It could hardly be possible in modern-day reality with its modulating, synergetic crossmotivations. Imperfection of human resources, a shortage of essential, pertinent information, the complexity of integrative communication (as well as particularity and privacy of the latter), temporal and source restrictions all harden the efficiency of applying strategic assessment methods and risk management. This in its stead causes favourable scenarios of network conflict interaction to be minimized and leads to consequent instability.

Thus the total absence of a universal vector in strategic risk management and an ever-rising uncertainty level lead to a break-up in the relationships between civil society, corporations and government that are vital for development of the state, and that in its turn results in a crisis in loyalty towards political decisions and the collapse in long-term political involvement. To highlight the idea even more, A. Aleinikov and A.Strebkov in their above-mentioned study articulate that 'conflicts get into the personal area (communication about each other rather than with each other), into striving to worsen any given conflict thus blocking any kind of dialog with the opposing party. Any compromise is then viewed as intolerable and shameful, with all legislative and moral standards of conflict resolution being cast off, especially while comparing behavioural scenarios of the opposing parties. At this stage the opposing party is definitely considered the source of all possible evil, which makes successful resolution virtually unobtainable, as any alternative viewpoint is absolutely unacceptable' [1, p. 36-37].

The diversity of the above-mentioned contradictions is accompanied by long-standing world crisis that is a hotbed where political risks may find new cognitive spaces. These accumulate not only within political systems themselves but also are forced from the outside. All this threatens the sovereignty of modern national states.

It seems quite evident that all these tendencies clearly cut out the dire necessity of turning to strategic risk management methodology, especially in the context of managing political conflicts in the governmental system. Moreover, understanding the nature of political risks and their structure encourages highlighting contradictions that occur in managerial technologies. This, in its turn, determines the emergence of a public discourse creating an advantageous environment for taking decisions of national importance, as well as communicative interactions that are mutually auspicious for all the participants in the conflict over political process. 
Taking into account all the global and national peculiarities of the managerial environment that were revealed above, the key task of strategic risk management is therefore providing necessary conditions for negotiating as many widespread 'trade-offs' (compromises) as possible on micro-, meso- and macro-levels. Let us dwell on the most important ones.

Applying risk management technologies on national and sub-national levels as a key step implies forming the scenarios that would provide state-society compromise. In that case it becomes vital to distinguish between the words 'consensus' and 'compromise. The difference was probably based on a famous quote by J. Lowell that 'compromise is a good umbrella but a bad roof: it may work quite well for some time; it is often used in the struggle of opposing political parties but it is virtually useless for managing the state. The term 'socio-political consensus' that is widely spread in Russian political science as an assessment category seems to be rather arguable from a methodological point of view. Reaching such a consensus appears troublesome in principle owing to the many peculiarities respective to the institutional and political design of modern Russian society. On the other hand, the phenomenon of 'political compromise' that is based on the mutual concessions is treated entirely differently in conflict studies where it is seen as reaching a balance of interests. If one takes $\mathrm{H}$. Simon's theory of bounded rationality as a starting point, one may identify that the main priority for a modern state is finding compromise strategies of conflict resolution and providing relatively stable social satisfaction with the results of political choice and exchange (satisfaction but not juxtaposing ultimate profits and expenses). This clearly leads to the opinion that risk management methodology today should mainly be founded on seeking the 'subjective expected utilities', described by H. Simon [6], in the process of shaping public policy that is aimed at stabilizing political order, and should not be directed by the principles that were extracted from the mixed-scanning model of impulse incrementalism by I. Etzioni [7] that at its best overcomes certain separate system gaps in management, while at its worst strives to acquire competitiveness that is hard to define and even harder to measure. The strategies which provide possible interaction scenarios for stakeholders and which are called to minimize the scenarios for seeking ultimate one-sided effectiveness (that is primarily the scenarios most advantageous for the ruling élite) will lead to working out the skills needed to take valuable decisions. These skills involve articulating the means of interaction between governmental and nongovernmental actors (both formal and informal), as well as creating the chance to arrive at a more efficient assessment of the conflict management in public policy as the whole. This means that the emphasis is shifted towards not only looking for a value-recognized basis for finding compromise both for the controlling and the controlled in the decision-making process, but mostly towards finding cognitive models which are targeted to eliminate indecisiveness in the expectations of political events and political decisions. The need for a complex analysis of the decision-making process that diminishes or de-escalates conflict, as well as makes decisions legitimate, is mainly defined by the ever expanding possibility of making preventive managerial decisions that can facilitate the shrinking or even wiping out the social damage and its consequences. It should also be kept in mind that dynamic technological advances and, as a consequence, rapid social development, make the topic of hidden and actual risks highly essential. In this way, the correlation in the managerial decision-making with respect to risk perception, as well as the way decision makers describe risks and the perception of danger by the people affected by them, becomes a 
clear indicator for eliminating the majority of conflicts in modern society. Therefore the compromise that was described above results in implementing a strategy of subdividing 'the right to make a decision into horizontal and vertical power structures and delegating some responsibilities to civil society structures' [8] which will eventually lead to intensifying the social effect of managerial investment - effects that are material, spiritual, intellectual, among others.

The following compromise is reached by setting a balance between administrative and political components that is hard to come to but, nonetheless, is crucial for hybrid regimes. We are talking about setting priorities and providing substantive and procedural rationality in public governance [6]. That essentially implies a wide range of contradictions and restrictions (mainly of a cognitive and heuristic character, and then motivational, resource-based, bureaucratic, institutional, corrupting, etc.) that stand in the way of fulfilling the patterns of strategic management. It becomes quite evident that private administrative activity by the officials of any rank could in no way be synonymous to working out national strategy that includes the quintessence of a wide range of interests and goals for all the participants in the political process, (i. e., the political elite, civil society, business structure, banks, foreign policy actors, etc.). Considering the issue from this angle, the mental basis for public administration starts from the classic definition of institutions supplied by D. North as man-made restrictions that constitute political, social and economic interaction [9], while at the same time public governance is more of a reflection by a governmental system on the fundamental socio-cultural, political, economic and other challenges, which result in producing the status that is meaningful for all the actors of public policy process. So it becomes crucial for societies that are prone to conflict to plan political governance in a strategic way. The main aim must be to diagnose the laws and probabilities of risk evolution that essentially lead to various social changes and to define possible options and work out the most efficient way of problem-solving that is based on the most adequate and up-to-date managerial decisions. If one agrees on the necessity of implementing the above-mentioned analytical methods, then one should keep in mind that the administrative management sector should have the required cognitive, informational and technological basis that is enough to fulfil the goals that are set. The key factors for working out national political course should be building effective communicational models with administrative units (setting strategy goals) and carrying out the whole supervising process afterwards. That way, combining the efforts of simultaneous introduction of risk management technologies into the administrative sector and the structures for producing national political decisions is aimed at minimizing risks of communication crises as well as administrative deviations and only then at delivering the best possible scenario of their interaction and providing mechanisms to facilitate quality feedback and thus harmonize the strategy of socio-political development in modern society.

The process of finding the next compromise shifts towards assessing the degree of representation in the practice of managing the closed (mainly hierarchically élite) and public (managerial) styles. The traditional public governance approach is based on the methodological assumption that public governance as a 'common good' can be treated as a public service. This makes providing the service strictly monopolized and set according to governmental standard. This way, the idea of A. Solovyev that 'governmental politics is an accumulation of internally bound goals that are based on the same principle and actions that are aimed at solving major social aims that are carried out by the government 
and civil actors on a certain organizational and statutory and regulatory basis' [10, p. 417]. This approach admits that in ever changing political and social links and relations a strict vertical type of organizing public management should not be used. The always expanding scale of network interactions of both a formal and informal kind open the way for introducing decentralized managerial technologies of conflict resolution, among which informational innovations are the most popular, such as Big-Data and 'cloud' technologies, 'new accountability', business planning and business engineering, designing etc.

Putting successful risk management into practice of political governance requires dramatic expansion of managing technology toolkit, mainly via applying various network methods and managing tools. Their primary task is then providing organizational and cognitive integration of numerous different actors.

In the governmental managing system (this concerns many different countries and not just Russia) decision making actors (politicians as well as bureaucrats) tend to specialize narrowly, thus making it even harder for various stakeholders to reach an agreement on decisions and strategies. There is a constant need for exchanging information, combining highly specialized personal sets of particular knowledge into more universal kit of common knowledge. In this sense, being ready to cooperate is a pre-requisite and necessary condition for providing efficient activities that are aimed at producing political decisions in a changing environment. So in such circumstances tools as crowdsourcing and benchmarking become more and more popular.

The appearance of crowdsourcing as a means for network interaction is directly connected with the development of information and communicative technologies and establishing economics that is based on knowledge. Numerous examples of using crowdsourcing clearly show that the Internet as a mechanism for instantaneous trans-border communication makes it possible for different organizations of the private and public sector to increase their investment and mobilizing potential, to form a positive image of a given territory and also provide broad access for discussions on the political decisions that are made.

The crowdsourcing method is founded on two key assumptions: first, that realizing your personal potential is one of the most important stimuli in the decision making process for individual actors in a modern society and, second, that a collective consciousness exists whose principal attractiveness lies in the fact that it is comprised of many separate intellects and is thus capable of arriving at a wide range of decisions [11, p. 79].

Collective consciousness could be defined as a certain form of knowledge that is spread everywhere, that is constantly on the rise and that could be coordinated, which in the long run encourages efficient mobilization of the abilities of miscellaneous actors [11, p.79]. In this sense, crowdsourcing is aimed at the final result (finding the perfect solution) rather than on characteristics of parties participating in working out and selecting the decision. So basically this type of technology should be described as egalitarian.

Another above-mentioned technology (benchmarking) could be described as an ever ongoing process of cross-measuring production, services and practical experience in relation to the strongest competitors in the area [12]. One should keep in mind that this comparison could be drawn not only among the organizations but also within each individual one of them, within their structural elements. This legitimately allows one to consider benchmarking as a way of constantly perfecting any type and level of organization and also a mechanism of comparison. 
Let us dwell a little bit more on the typical traits that distinguish benchmarking which is put into practice in the private as well as the public sector. Benchmarking constantly stakes the organization's practise against the best possible examples, incessant case studies that are well beyond the traditional framework of the organization, adapting and putting into active practice the information acquired. Benchmarking is used not only vertically (i.e., monitoring productivity from local authorities to the central government, to say nothing of private service providers), but also horizontally (at the point when organizations voluntary participate in systematic research procedures) [12]. The most widely used tool for horizontal benchmarking is probably organizational education that is targeted at improving management by incorporating the need for innovations into behavioural practice.

Different types of crowdsourcing, together with the benchmarking method, comprise the foundation for network interaction in the process of providing effective strategic development of territories and introducing risk management into all political governance. These technologies are actually capable of forming global networks of interaction between people who are united by shared interests, of increasing production competition, adaptability of the managing system as well as the society as a whole.

Although the predominance of hierarchy models certainly hinders analysis of the introduction of strategic risk analysis technologies into public governance in our country, if one is careful to consider certain restrictions, then one can survey the risks caused by modernizing. One can then assess the resulting functioning in an administrative sector with an open style organization, broadening the scope of horizontal interactions and measuring against the central indicator.

In this particular context risk analysis is definitely of a total character; i.e. includes all levels of organizations that are responsible for setting goals, gathering information and setting the rules and regulations of administrative activities. While latent vertical coordination prevails inside structures, they are aimed at engineering political decisions on a national level of public governance that has a distinctive corporate monopoly and oligarchical nature. This makes it next to impossible to 'clearly measure the efficiency of the power-regulating activity' [13, p. 61-64] and makes it hard to assess risks and generate recommendations that are based on risk analysis. This collision points out the dire necessity for having risk analysis without incorporating the global political course into their structure. One possible solution to this problem lies in studying the risks of modern management as a key element in transforming contemporary political systems. This, in turn, enables one to focus one's attention on the public sphere that is, in fact, produced by global political management risks themselves rather than personifying network interactions between political actors and the decisions they make that possess a latent nature. This brings one to the conclusion that there could be only one criterion to estimate efficiency - a country's basic vitality; i.e. the guarantee of its international safety, political stability, national, spiritual and moral identity. Without aligning goals, social roles and managerial actions it is very easy for authorities to lose direction, at the same time being tortured by mutual mistrust, suspicions, inner disagreements and scheming. Plans lose all influence, degrade and eventually die. This essentially means that the primary task for risk management, after having made profound analysis of the environment that is created by latent network interactions, is assessing the amount of damage that was caused by the decisions made and to stop risks from transforming into irrevocable dangers to the state 
as they will then go on to threaten national security. By complementing for the analysis of latent and public interactions in governmental management structures, one must first admit to the symbiosis of hidden alliances with vertical coordination and open managerial decentralization. Then it is possible to take the steps required to prevent a shift in serious conceptual focus. Instead of subject analysis of the already existing events, researchers tend to voice abstract (necessary and/or sufficient) mechanisms of estimating political and managerial processes, which are somehow imported from other nations' experience, and which mostly are unsuitable in a political, economic and socio-cultural sense for modern Russia. This leads to a low level of theoretical coherence that is crucial for the risk studying area. Controlling risks in this sense should be viewed as not only a process of reducing and restraining the appearance of negative events but also as a process of increasing the potential for the emergence and the intensification of positive events, which in its course means providing effective scenarios for the public policy process.

Rendering the latter compromise is determined by establishing a fine balance between the inner stability and the outer competitiveness of the state. The efficacy of political strategies in the evolution of this or that political system and its organizational structures depends on whether the political system clearly shows its political borders, effectively differentiates itself 'within' and in other systems. A system that is unable to sustain its own political identity and its distinction from other countries loses the potential for political adaptation and unmistakably exhibits the faultiness of its institutions. Such political identity becomes a political and cultural condition for risk compatibility in making political decisions and the readiness of its citizens for political mobilization. Strategic risk management thus becomes a tool for justification of manifold political decisions and their being legitimate according to expecting the equilibrium of all the participants in the political process, in that way creating public space and effective identity for the national political system and proving high adaptable 'societality' of the political process.

However, political processes today apparently manifest determination of factors shaping inner stability of the state with an incessant rising number of outer challenges that cause threats to national security and stability. Globally speaking, this alludes to risks which implicate the loss of competitiveness of a modern state. The classic definition of competitiveness was put forward by M. Porter, who classifies this phenomenon as retaining the competitive advantages of a state by implementing modern innovations [14]. It is noteworthy that nowadays political competitiveness is a direct reflection of the economic one. At present one can distinct two methodological approaches to complex assessments of national competitiveness: the calculation of the general integral index and calculation of the integral index on the basis of comparing the indicator being analysed with an average level at the national cross section. M. Porter in his work entitled 'International competition. Competitive advantages of states' comes to the conclusion that the index estimation of competition used nowadays by their formal 'comparative exponents' (climate, natural resources, etc.) is not considered effective. It seems more relevant to turn to the competitive advantage actually created by the state. The basis of this advantage lies in the intellectual management and incorporating innovations with risk management in mind, and not the urge to show results that are comparable with the 'convenient' worldwide ones. It may work well to start reforming according to the modern economics model that was described by the academician V. Polterovich. It includes finding grounds for such strategic planning measures of strategic regulation as: 
1. reasonably limited use of western technologies,

2. a balanced policy of openness,

3. self-restriction imposed by the élite,

4. tax policy measures,

5. creation and support of miscellaneous projects.

On top of these, the index of absorption capability of the country must be increased in a manner that could lead to forming a large scale national innovation system based on strategic thinking and risk management [15]. The absorption capability of the state, which is traditionally defined as work skills related to treating outer information and setting strategies accordingly, seems to be the best criterion that provides the competitiveness of modern states whose political development strategies are founded on an imitation principle. It is worth mentioning, however, that the development potential achieved by catching up is limited due to being only imitative. Developing countries can not get immediate access to the cutting edge technologies and so the gap between them and the leading countries does not diminish [16].

The analysis of risk limitations indicates that the Russian Federation demonstrates a very low level of benchmarking. Thus it seems worthwhile to separately examine basic risks that determine the state's low absorption ability: the underdevelopment of networks that spread knowledge and innovations, the imperfection of the institutional and regulatory base (patent system), the limitations of motivational intentions in the human capital structure, insufficient competition analysis of foreign technologies that already exist, an unwholesome investment climate, and many others. This brings one to the logical conclusion that, as modern states rapidly develop, permanent modernizing of the economic system and lowering the risks of losing economic and then political competitiveness guarantees stable inner system indexes. Moreover, being integrated into the international innovation system, Russia automatically becomes a society of widespread risk. It is generally known that building a risk society has become a global trend [5]. Then the task of seeing the place of Russia's integration in the society of global risks and producing recommendations that will dramatically alleviate outer threats is becoming crucial.

To draw the line under our arguments in the present article, it is vital to note that there are two major characteristics of strategic conflict risk management that distinctly show wide scope of its potential use in modern political space. First, modern risk management is an integral characteristic of political and managerial discourse. This essentially means that, on the one hand, the accumulation of political risks in modern societies leads to unforeseeable dangers for the authorities and society, thus threatening national security. On the other hand, political risks are a heuristic category in political management analysis that allows one to better examine the very structure of modern risks, to form new communicative spaces for managing conflicts that are advantageous for implementing political strategies. Moreover, public management in Russia has a limited understanding of risks. It is not enough to perceive risks as an unknown consequence of public governance that, as the worst case scenario, can lead to the loss of stable development. This process has another side to it. The unwillingness to make political decisions in unstable conditions sometimes brings about more and more falling behind states that are already incorporated into the global risks society and that have already learned to make effective decisions that are adequate for the circumstances of the uncertainty. One more case in point is rapid growth of various venture funds that are almost synonymous to modern innovations. So 
all the efforts that the authorities make 'to avoid the risks of making decisions in the situation of uncertainty, cuts off the chance for further evolutionary development and the country has to agree to the future "hasty" decisions and to the loss of social stability yet to come. While trying to avoid the catastrophe, the authorities in fact doom themselves to the struggle with "excess social diversity" [8].

The second major characteristic of modern risk management is finding ways to intensify its preventive impact on conflict potential. Building a model that allows for the management of risks and is based on assessing them, choosing relevant tools to implement them, and smoothing their potential negative effects presents itself as a highly vital research task. The outlook of modernization in the country can be shaped by implementing into the process of making political and governmental decisions important operational changes developed by research that has a logical, informational, cognitive, semantic, symbolic, behavioural and organizational nature. Systemic risk management at the stages of generating and implementing state policy will encourage levels of efficiency, legitimacy, rationality and optimization of the public governance system. At once decreasing bias and randomness, as well as increasing the transparency and soundness of the decisions made, measuring their effectiveness based on a system of relevant indicators, making wise choices of strategic decisions founded on alternative versions - all these will provide purposefulness, consistency and the swift flow of public governance. This will also ensure at the same time that the application of potentially dangerous procedures that threaten the stability of modern day Russia will be kept to a minimum. It seems likely that systematic analysis of social, cultural, demographic, behavioural, institutional, communicative, informational and other factors will still have a crucial influence on the crisis activities in Russia as they exhibit different dynamics, vectors, and as they act at various levels,. It is also important to remark that any change requires a project approach to solving social problems based on complex and systematically applied methods. The strategy of risk management makes it possible to synchronize both the goals and resources. Without strategic management it is impossible to unravel risks, identify them, analyse all the interconnections of factors involving them, establish their possible extent, and measure their intensity. This clearly manifests the need for the conceptual 'rebirth' of strategic management methodology for its future use in risk analysis for a harmonization of the public policy process.

\section{References}

1. Aleinikov A. V., Strebkov A.I. Konflikty i sotsial'naia stabil'nost'v sovremennoi Rossii [Conflicts and social stability in modern Russia]. Voprosy filosofii, 2015, no. 12, pp. 27-41. (In Russian)

2. Kapustin V.S. Sinergetika sotsialnykh innovatsionnykh protsessov [Synergetics of social innovative processes]. Available at: http://spkurdyumov.narod.ru/Kpstn.htm (accessed: 5.10.2017). (In Russian)

3. Pavlovsky G. O. Genial'naia vlast'! Slovar' abstraktsii Kremlia [Ingenious authorities! A dictionary of the Kremlin abstractions]. Moscow, Evropa Publ., 2012. 110 p. (In Russian)

4. Taleb N. The Black Swan: The Impact of the Highly Improbable. New York, Random House Publishing Group, 2007. 400 p.

5. Beck U. Risk Society, Towards a New Modernity, translated from the German by Mark Ritter, with an Introduction by Scott Lash and Brian Wynne. London, Sage Publications, 1992. 272 p.

6. Simon H. Rationality as Process and as Product of Thought. Richard T. Ely Lecture. American Economic Review, 1978, vol. 68, no. 2, pp. 1-16.

7. Etzioni A. Mixed Scanning: A “Third” Approach to Decision-Making. Public Administration Review, 1967, vol. 27, no. 5, pp. 385-392. 
8. Kapustin V.S. Analiz riskov administrativnogo upravleniia: sinergeticheskii podkhod [Risk analysis of administrative management: synergetic approach]. Available at: http://nonlin.ru/node/80 (accessed: 04.10.2017). (In Russian)

9. North D. Institutions. Journal of Economic Perspectives, 1991, vol. 5, no. 1, pp. 97-112.

10. Solovyov A. I. Priniatie i ispolnenie gosudarstvennykh reshenii [Taking and execution of the state decisions]. Moscow, Aspect Press, 2014. 496 p. (In Russian)

11. Kurochkin A. V. Kraudsorsing kak novyi metod politicheskogo upravleniia v usloviiakh setevogo obshchestva [Crowdsourcing as a new method of public governance in the network society]. Istoricheskie, filosofskie, politicheskie i iuridicheskie nauki, kulturologiia $i$ iskusstvovedenie. Voprosy teorii i praktiki [Historical, philosophical, political and judicial science, culture and art studying. Theoretical and practical issues], 2013, no. 9 (35), pp. 78-81. (In Russian)

12. Eremeev S. G., Kurotchkin A.V. Gosudarstvennoe upravlenie i innovatsionnaia politika $v$ usloviiakh setevogo obshchestva: Novye printsipy effektivnosti [Public governance and innovative policy in a network society. New effectiveness principles]. St. Petersburg, Russian Christian Humanitarian Academy Publishing House, 2014. 192 p. (In Russian)

13. Ohotskiy E. V. Upravlencheskie patologii gosudarstva: neopredelennosti, disfunktsii, sotsial'nye riski [Administrative pathologies of the state: uncertainty, dysfunctions, social risks]. Srednerusskii vestnik obshchestvennykh nauk, 2016, no. 2, pp. 57-70. (In Russian)

14. Porter M. The Competitive Advantage of Nations. New York, Free Press, 1990. 855 p.

15. Polterovich V. M. Strategii modernizatsii, instituty i koalitsii [Strategies of modernization, institutes and coalitions]. Voprosy ekonomiki, 2008, no. 4, pp. 4-24. (In Russian)

16. Kuts V.I. Absorbtsionnaia sposobnost' natsional'noi ekonomiki kak uslovie rosta konkurentosposobnosti natsional'noi promyshlennosti [Absorption capacity of a national economy as condition of the national industry competitiveness growth]. Voprosy ekonomiki i prava, 2011, no. 8, pp. 95-100. (In Russian)

Received: 11.01.2018

Accepted: 08.02.2018

Author's information:

Alexander V. Kurochkin - Dr. Sci. in Political Science, Professor; a.kurochkin@spbu.ru

Daria A. Maltseva - PhD, Associate Professor; d.maltseva@spbu.ru

\title{
Инструментарий стратегического риск-менеджмента в публичной политике: конфликтологический подход
}

\author{
А. В. Курочкин, Д. А. Мальцева \\ Санкт-Петербургский государственный университет, \\ Российская Федерация, 199034, Санкт-Петербург, Университетская наб., 7-9
}

Для цитирования: Kurochkin A. V., Maltseva D. A. Strategic risk management in public policy: Conflict study approach // Вестник Санкт-Петербургского университета. Философия и конфликтология. 2018. Т. 34. Вып. 2. С. 264-276. https://doi.org/10.21638/11701/spbu17.2018.210

Статья посвящена анализу места и перспектив применения инструментов стратеги-
ческого риск-менеджмента в процессе государственного управления в условиях не-
стабильного, высококонфликтогенного общества. Ключевой целью статьи является
выбор методологии для формирования эффективной модели управления рисками
на основе их комплексной оценки и определения адекватных инструментов, снижа-
ющих уровень конфликтности и сглаживащих возможные негативные последствия
конфликтов. Чрезвычайно высокий динамизм современных социально-политических,
экономических и культурных процессов, а также обычно запаздывающая реакция
на них со стороны государственного аппарата требуют изменения подходов в опре-
делении стратегий развития, оценке регулирующего воздействия; расширения круга 
стеэйкхолдеров, вовлекаемых в процесс принятия решений. Публичные решения должны получить методологическое и методическое обоснование как интегральные решения, связанные с координацией разнообразных целей в процессе выработки политики. Глубинное исследование действенных административно-управленческих механизмов, способных обеспечить общественное согласие и снизить уровень конфликтогенности, помимо прочего позволит смоделировать новые коммуникативные пространства, поддерживающие должный уровень корреляции государственных интересов с публичными запросами и потребностями, с публичным порядком и заданными параметрами эффективности политических стратегий, а также сформировать реальные механизмы резистентности государства к дестабилизирующим негативным факторам. В статье доказано, что в условиях высококонфликтогенных обществ витальное значение приобретают такие управленческие функции, как прогнозирование, стратегическое проектирование и моделирование. Их основной целью становятся диагностика закономерностей и факторов развития рисков, ведущих к значительным социальным переменам, определение возможных сценариев развития и выработка наиболее эффективных способов решения проблем в будущем. Такой подход дает возможность не только сформировать фундаментальные основания выработки политики прогнозирования, предупреждения и управления конфликтами, примирить частные и публичные интересы, но также попытаться снизить уровень социально-политической неопределенности.

Ключевые слова: конфликты, риски, риск-менеджмент, стратегическое управление, публичная политика, публичные интересы.

Контактная информация:

Курочкин Александр Вячеславович - д-р полит. наук, проф.; a.kurochkin@spbu.ru Мальцева Дарья Александровна - канд. полит. наук, доц.; d.maltseva@spbu.ru 